\title{
Evaluation of an antibacterial orthodontic adhesive incorporated with niobium-based bioglass: an in situ study
}

Felipe Weidenbach DEGRAZIA(a) Aline Segatto Pires ALTMANN(a) Carolina Jung FERREIRA ${ }^{(a)}$ iD Rodrigo Alex ARTHUR(b) Vicente Castelo Branco LEITUNE(a) Susana Maria Werner SAMUEL(a) Fabrício Mezzomo COLLARES(a)

(a) Universidade Federal do Rio Grande do Sul - UFRGS, School of Dentistry, Dental Materials Laboratory, Porto Alegre, Rio Grande do Sul, Brazil.

(b) Universidade Federal do Rio Grande do Sul - UFRGS, School of Dentistry, Biochemistry and Oral Microbiology Laboratory, Porto Alegre, Rio Grande do Sul, Brazil.

Declaration of Interests: The authors certify that they have no commercial or associative interest that represents a conflict of interest in connection with the manuscript.

Corresponding Author:

Fabrício Mezzomo Collares

E-mail: fabricio.collares@ufrgs.br

hitps://doi.org/10.1590/1807-3107bor-2019.vol33.0010

Submitted: June 18, 2018

Accepted for publication: November 27, 2018

Last revision: January 09, 2019
Abstract: This in situ study aimed to evaluate the antibacterial and anti-demineralization effects of an experimental orthodontic adhesive containing triazine and niobium phosphate bioglass (TAT) around brackets bonded to enamel surfaces. Sixteen volunteers were selected to use intra-oral devices with six metallic brackets bonded to enamel blocks. The experimental orthodontic adhesives were composed by $75 \%$ BisGMA and 25\% TEGDMA containing 0\% TAT and 20\% TAT. Transbond XT adhesive (TXT) was used as a control group. Ten volunteers, mean age of 29 years, were included in the study. The six blocks of each volunteer were detached from the appliance after 7 and 14 days to evaluate mineral loss and bacterial growth including total bacteria, total Streptococci, Streptococci mutans, and Lactobacilli. Statistical analysis was performed using GLM model - univariate analysis of variance for microhardness and 2-way ANOVA for bacterial growth $(\mathrm{p}<0.05)$. The $20 \%$ TAT adhesive caused no difference between distances from bracket and the sound zone at $10-\mu \mathrm{m}$ deep after 7 and 14 days. After 14 days, higher mineral loss was shown around brackets at $10-$ to $30-\mu \mathrm{m}$ deep for TXT and 0\% TAT adhesives compared to 20\% TAT. S. mutans growth was inhibited by $20 \%$ TAT adhesive at 14 days. Adhesive with 20\% TAT showed lower S. mutans and total Streptococci growth than $0 \%$ TAT and TXT adhesives. The findings of this study show that the adhesive incorporated by triazine and niobium phosphate bioglass had an anti-demineralization effect while inhibiting S. mutans and total Streptococci growth. The use of this product may inhibit mineral loss of enamel, preventing the formation of white spot lesions.

Keywords: Tooth Remineralization; Anti-Infective Agents; Dental Enamel; Orthodontics.

\section{Introduction}

Prolonged retention of dental plaque, especially the microorganism Streptococcus mutans, around brackets during orthodontic treatment with fixed appliances leads to a decrease of $\mathrm{pH}$ and thus the development of white spot lesions (WSLs) in the enamel surface. ${ }^{1}$ Brackets and archwires usually create numerous retention sites hampering tooth cleaning. Current 
clinical investigations $\mathrm{s}^{2,3}$ have reported an increase of WSLs prevalence from 46 to $59 \%$ for patients whose hygiene worsened after 12 months of orthodontic treatment. In addition, the majority of patients undergoing orthodontic treatment are teenagers who often have suboptimal manual ability and overall motivation. ${ }^{4}$ These findings highlight the necessity to use supplementary preventive methods to avoid demineralization of the enamel surface.

In line with previous efforts to find novel anticaries and remineralization agents with additional or synergistic effects, some agents, such as triclosan, chlorhexidine, and silver, have been added to orthodontic adhesives resulting in antimicrobial activity. ${ }^{5,6,7}$ Although some authors have indicated a decrease in bond strength after addition of antibacterial agents, a meta-regression analysis demonstrated that this procedure has no influence in bond strength to enamel. ${ }^{8}$ Recent in vitro studies have shown inhibition of bacterial growth with methacrylatebased monomers, such as 1,3,5-triazine. ${ }^{9,10}$ This antimicrobial agent is a small compound that mimics the hydrophobic pattern of short cationic peptides. It can decrease bacterial growth by disrupting the membrane integrity and is more selective against gram-positive bacteria. ${ }^{11}$

Notwithstanding, the use of bioactive fillers have been the reason of current studies in order to recover mineral content of dental tissues. ${ }^{5,11,12}$ One of this materials is phosphate invert glass (PIG), which stimulates a specific biological response, resulting in a bond between living tissue and synthetic material. ${ }^{13}$ Furthermore, niobium pentoxide has shown to promote mineral deposition when in contact to artificial saliva ${ }^{10,14}$ Its addition to PIG could enhance chemical stability ${ }^{15}$ leading to a long-term effect of bioglasses. Recent in vitro studies ${ }^{10,16}$ evaluated the performance of an experimental orthodontic adhesive incorporated with PIG and niobium pentoxide, which showed improved mechanical and chemical properties. Considering the limitations of in vitro studies in simulating daily changes of sugar exposure, $\mathrm{pH}$, saliva, temperature, humidity, and bacteria colonization of the oral environment, in situ models represent an adequate approach. In situ studies are a relatively fast and clinically relevant method $^{17}$ to study the behavior of antibacterial adhesives against demineralization caused by dental plaque.

Therefore, this study aimed to evaluate in situ the antibacterial and anti-demineralization effects of an orthodontic adhesive incorporated with triazine and niobium pentoxide phosphate invert glass (TAT). The null hypothesis was that the adhesive containing 20\% wt triazine and 5\% wt niobium phosphate bioglass (20\% TAT) would present no difference in mineral loss and bacterial growth compared to other adhesives and its sound zone.

\section{Methodology}

The study was approved by an Ethical Committee Board (CAAE 49445515.7.0000.5347) and followed the guidelines of the Declaration of Helsinki.

\section{Preparation of the experimental adhesives}

The experimental orthodontic adhesives were prepared with 75\%/25\% BisGMA and TEGDMA methacrylates, and a photo-initiator (CQ: Camphorquinone, $1 \mathrm{~mol} \%$ ) and two co-initiators (EDAB: ethyl 4-dimethylaminobenzoate; DPIHFP: diphenyliodonium hexafluorophosphate, $1 \mathrm{~mol} \%$ each) (Aldrich Chemical Co., Milwaukee, USA) were used. Also, $5 \%$ wt of fumed silica (AEROSIL 200, without silane, Piscataway, USA) were added to adjust the viscosity, as previously reported..$^{9}$ The compound 1,3,5-tryacryloylhexahydro-1,3,5-triazine (TAT; Sigma-Aldrich, St. Louis, USA) was added at $20 \% \mathrm{wt}$ as described in a recent study. ${ }^{14}$ Phosphate invert glass containing $10 \mathrm{~mol} \%$ of niobium pentoxide (PIG-Nb) with a mean size of $74 \mu \mathrm{m}$ was prepared as previously reported ${ }^{16}$ and added at $5 \% \mathrm{wt}$.

\section{Study design}

The study presented a double-blinded (volunteers and outcome assessor) and controlled in situ design. The factor evaluated was orthodontic adhesive resin: Group TXT, Transbond XT primer+Transbond XT adhesive (3M Unitek Corp, Monrovia, USA); Group $0 \%$ TAT, experimental orthodontic adhesive; and Group 20\% TAT, experimental orthodontic adhesive with TAT + PIG-Nb. 


\section{Sample size}

The sample size of 13 volunteers was calculated for a $5 \%$ significance level, $80 \%$ power, $7.4 \%$ of enamel microhardness loss as estimated standard deviation, and $7.7 \%$ as minimum detectable difference in means of enamel microhardness loss based on the demineralization data of a previous study. ${ }^{18}$ Three extra individuals were added expecting a dropout rate of $20 \%{ }^{19}$

\section{Sample preparation}

Enamel blocks $(\mathrm{n}=140,5 \times 5 \times 2 \mathrm{~mm})$ were prepared from sound bovine teeth $(\mathrm{CF})$. The teeth were stored for 1 month in distilled water then cut with a diamond saw (IsoMet, Buehler Ltd., Lake Bluff, USA) and their surfaces were ground flat with \#600-, \#1200-, and \#2000-grit silicon-carbide papers. One hundred and eight blocks were selected after microhardness measurement by the closest values to the total average value $(257 \pm 0.9)$. The mean hardness of the blocks of each appliance was similar to the total average value.

The bonding of metallic orthodontic brackets (Morelli Ltd., Sorocaba, Brazil) was performed by etching the enamel for $30 \mathrm{~s}$ with $37 \%$ phosphoric acid (CaiTECH Ind. Ltd, Rio do Sul, Brazil), rinsing with water, and drying with oil-free compressed air until the etched enamel showed a frosty appearance. A thin layer of Transbond adhesive primer (3M Unitek, Monrovia, USA) was applied with a micro-brush and photo-activated for $20 \mathrm{~s}$ before adhesive resin application. The adhesive resin of each group (TXT, $0 \%$ TAT and $20 \%$ TAT) was applied with a syringe and brackets were pressed with a $300 \mathrm{~g}$ needle. ${ }^{9}$ The adhesive excess was removed and the resin was photo-activated for $10 \mathrm{~s}$ on each side of the bracket by light-emitting diode RadiiCal $\left(1200 \mathrm{~mW} / \mathrm{cm}^{2}\right.$; SDI Ltd., Bayswater, Australia).

Intraoral palatal appliances were made for the upper arch with acrylic resin on plaster models. Each appliance had six wells $(6 \times 6 \times 3 \mathrm{~mm})$, three on each side, with one well for each enamel block. The position of enamel blocks in the wells was randomly determined by a software program (Research Randomizer Form, Social Psychology Network, Middletown, USA) for each volunteer. The enamel blocks were fixed with cyanoacrylate $1 \mathrm{~mm}$ below the level of the appliance surface in order to induce dental plaque accumulation (FD and $\mathrm{CF}$ ).

\section{Volunteers and In situ experiment}

Sixteen volunteers of the 31 students/professors from the Faculty of Dentistry fulfilled the inclusion criteria (18+ years old; adequate oral health with no caries, erosive lesions and gingivitis/periodontitis) and were selected after verification of the exclusion criteria - medication that affects salivary glands, systemic disease influencing oral function, smoking, pregnancy, use of antimicrobials within 90 days before the start of the study, and orthodontic treatment (Figure 1). The volunteers received verbal and written instructions about the protocol. They also received a $30-\mathrm{mL}$ bottle containing $20 \%$ sucrose solution, the orthodontic appliance and container, a fluoride toothpaste (1350 ppm), and a soft toothbrush.

Volunteers were instructed to wear the orthodontic appliance for two weeks, $24 \mathrm{~h}$ a day, except during meals, avoid drinking anything that could be an additional source of fluoride, and brush the sample holders. The volunteers applied a drop of sucrose solution 8 times per day, every $2 \mathrm{~h}$, and after 5 minutes, ${ }^{20}$ and clean the device outside the mouth, avoiding the wells, once a day with the fluoride toothpaste. After 7 days, the three blocks of the left

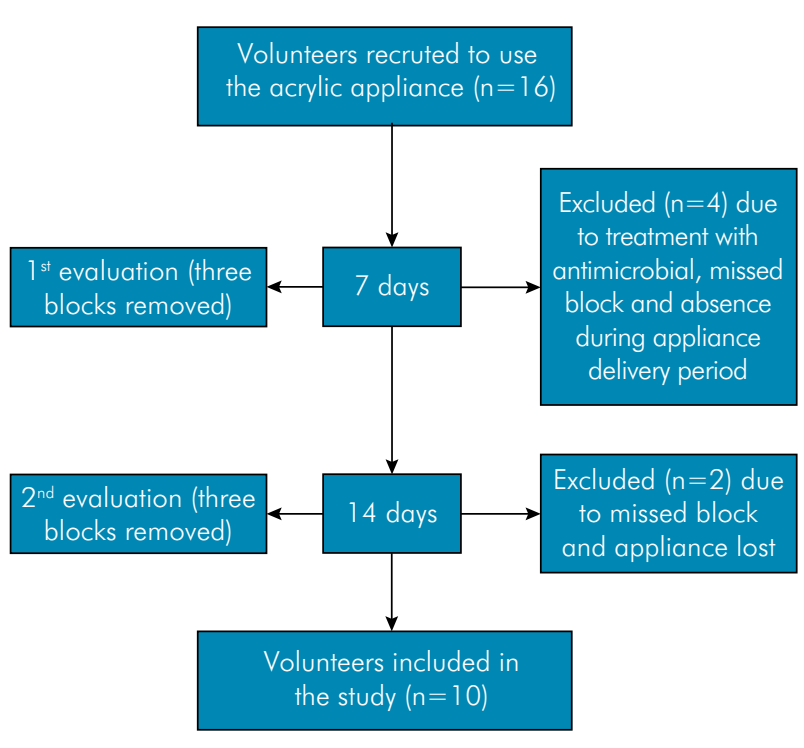

Figure 1. Flowchart of volunteers included/excluded in the in situ study. 
side of the appliances were removed to perform mineral loss measurements and bacterial growth assays and the sample holders were filled with wax. After 14 days, the same evaluations were performed in the blocks of the right side.

\section{Mineral loss measurement}

Sixty enamel blocks with bonded brackets were sectioned in the buccal-palatal direction with a diamond disk in the cutting machine. The half-blocks were embedded in acrylic resin and polished with \#2000-grit silicon carbide paper and felt disc with aluminum oxide solution. Following a previous study, ${ }^{18}$ 42 indentations were made in each half-block with a microhardness tester HMV-2 (Shimadzu Corp., Kyoto, Japan) under a load of $25 \mathrm{~g}$ for $5 \mathrm{~s}$. Six indentations (at 10, 20, 30, 50, 70, and $90 \mu \mathrm{m}$ from the bracket) at 7 mesial-distal positions (at the center relative to the bracket and at $0 \mu \mathrm{m}$ (edge of the bracket), 100, and $200 \mu \mathrm{m}$ from the bracket), were made on the occlusal surface. The Knoop hardness values from two halfcrowns and from each side were averaged.

\section{Bacterial composition}

The composition of the biofilm accumulated during 7 and 14 days of experiment was analyzed by the bacterial adherence assay. Six enamel blocks covered by oral biofilm of each of the 10 adhesive groups (total of 60 ) were removed from the appliances and transferred to a microtube containing $900 \mu \mathrm{L}$ of sterile saline solution $(0.9 \% \mathrm{NaCl})$. After, biofilms were harvested and the bacterial suspensions were serially diluted $(100 \mu \mathrm{L})$ in saline solution. Two aliquots of $25 \mu \mathrm{L}$ were plated onto the mediums $(n=3)$ agar sanguis, agar mitis salivarius, agar mitis salivarius + $0.2 \mathrm{U} / \mathrm{mL}$ bacitracin, and agar rogosa $\mathrm{SL}$ to determine the number of total bacteria, total Streptococci, S. mutans, and Lactobacilli, respectively. All plates were incubated under microaerophilic conditions at $37^{\circ} \mathrm{C}$ for $48 \mathrm{~h}$, followed by counting the colony-forming units (CFUs). ${ }^{21}$ The number of CFUs was visually counted by two blinded researchers (F.D. and C.F.) using an optical microscope. The mean value was scored and transformed to log CFU per milliliter.

\section{Statistical analysis}

Microhardness data of the four factors (time, distance, depth, and adhesive) and their interactions were evaluated by univariate analysis of variance (ANOVA) followed by Tukey's test. Bacterial composition $\left(\log _{10} \mathrm{CFU} / \mathrm{mL}\right)$ was evaluated by twoway ANOVA with a 0.05 level of significance. Analyzes were performed on SigmaPlot 13.0 Software (Systat Software Inc., San Jose, USA).

\section{Results}

The ten volunteers ( 6 females, 4 males, aged 21 to 36 years) attended the university clinic at 7 and 14 days. Four volunteers dropped out of the study in the first week due to absence $(n=2)$, block lost $(n=1)$, or antimicrobial use $(n=1)$. Two volunteers dropped out during the second week due to lost sample or lost appliance (Figure 1).

Significant effects were found for the four factors: time, distance, depth, and adhesive ( $p<0.05)$, and for the interactions time*adhesive and distance ${ }^{*}$ adhesive $(\mathrm{p}<0.05$; Table 1; Figure 2 and 3).

Table 1. Univariate analysis of variance results for microhardness.

\begin{tabular}{lccccc}
\hline Source & Sum of squares & Mean square & df & $F$ & $P^{\prime}$ \\
\hline Time & 144.520 .469 & 144.520 .469 & 1 & 29.455 & 0.0001 \\
Distance & 86.121 .528 & 28.707 .176 & 3 & 5.851 & 0.001 \\
Depth & 2.515 .204 .616 & 503.040 .923 & 5 & 102.527 & 0.0001 \\
Adhesive & 229.273 .211 & 114.636 .605 & 2 & 23.365 & 0.0001 \\
Time*Adhesive & 429.215 .288 & 214.607 .644 & 2 & 43.740 & 0.0001 \\
Distance*Adhesive & 62.594 .327 & 10.432 .388 & 6 & 2.126 & 0.048 \\
\hline
\end{tabular}

'Statistically significant $(p<0.05)$. 
Mineral loss of the $0 \%$ TAT group, after 7 days of experiment, at distances of $200 \mu \mathrm{m}$ and "Sound zone" was significantly lower $(\mathrm{p}<0.05)$ than TXT and $20 \%$ TAT at 50, 70 and $90 \mu \mathrm{m}$, and $70 \mu \mathrm{m}$ depth, respectively. However, after 14 days of experiment, mineral loss of the $20 \%$ TAT group was significantly

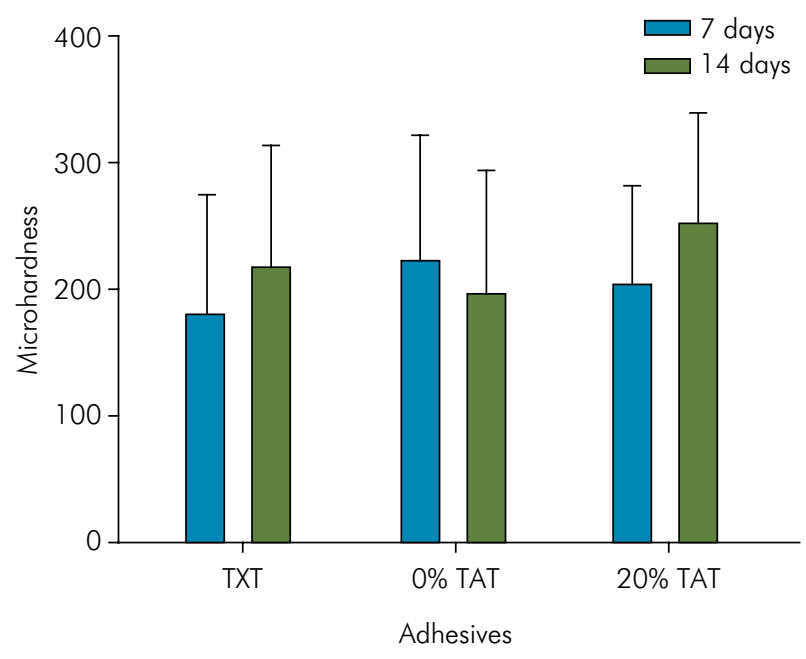

Figure 2. Mean and SD values of enamel microhardness according to time ( 7 and 14 days) and adhesive (TXT, 0\% TAT, and $20 \%$ TAT). lower $(\mathrm{p}<0.05)$ than TXT (at distance of $100 \mu \mathrm{m}$ and $10 \mu \mathrm{m}$ depth) and $0 \%$ TAT (at distances of $0 \mu \mathrm{m}$ and $100 \mu \mathrm{m}$, with $50 \mu \mathrm{m}$ and $30 \mu \mathrm{m}$ depth, respectively), as shown in Table 2. Representative images (Figure 4a to 4 d) show the mineral increase of TXT and 20\% TAT at 7 days compared to 14 days of the experiment.

The experimental orthodontic adhesive containing $20 \%$ TAT and 5\% PIG-Nb was effective in preventing demineralization around metallic brackets bonded to enamel surface $(\mathrm{p}<0.05)$ after 7 and 14 days (Figure 5a and 5b; Table 2) compared to TXT and $0 \%$ TAT groups.

Regarding mineral loss within groups among various distances, significant differences $(p<0.05)$ were found at $10 \mu \mathrm{m}$ depth. No difference $(\mathrm{p}>0.05)$ was found after 7 and 14 days in the 20\% TAT group. Increased mineral loss was found after 7 days in the TXT group in "Sound zone" compared to 100 and $200 \mu \mathrm{m}$ and in the 0\% TAT group in "Sound zone" compared to $100 \mu \mathrm{m}$ (Figure 5a). After 14 days, increased mineral loss was found in the TXT group in "Sound zone" compared to 0 and $100 \mu \mathrm{m}$ (Figure 5b). Inhibition of bacterial growth $(\mathrm{p}<0.05)$ between 7 and 14 days was found only in the 20\% TAT group

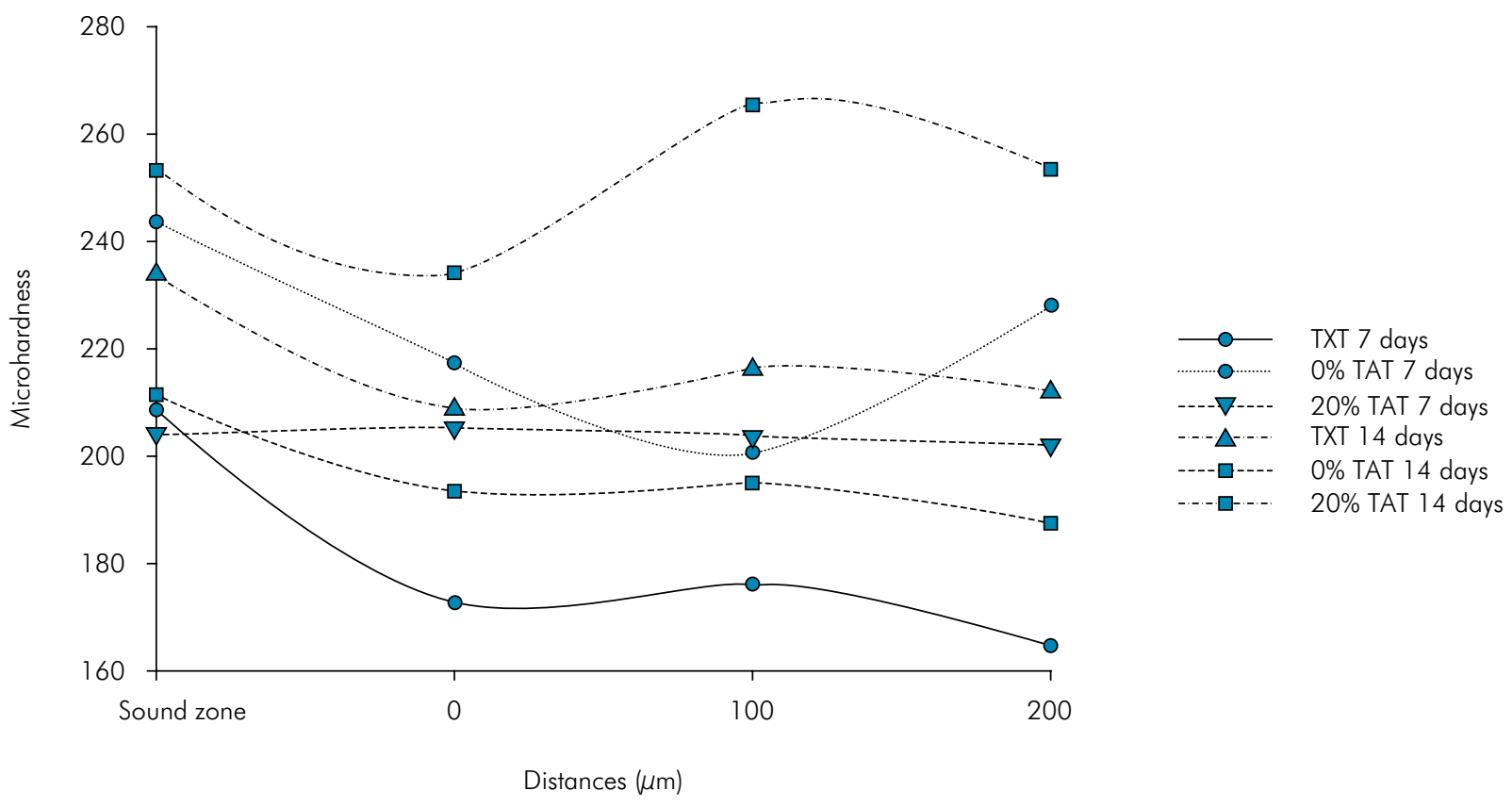

Figure 3. Mean values of enamel microhardness according to adhesive (TXT, 0\% TAT, and 20\% TAT) and distances (Sound zone, $0,100$, and $200 \mu \mathrm{m})$. 
- Evaluation of an antibacterial orthodontic adhesive incorporated with niobium-based bioglass: an in situ study

Table 2. Mean and SD of microhardness (depth and distance, in $\mu \mathrm{m}$ ) of different groups after 7 and 14 days of bacterial accumulation.

\begin{tabular}{lcccccccc}
\hline \multirow{2}{*}{ Variable } & \multicolumn{2}{c}{ Total bacteria } & \multicolumn{2}{c}{ Total Streptococci } & \multicolumn{2}{c}{ S. mutans } & \multicolumn{2}{c}{ Lactobacillus } \\
\cline { 2 - 9 } & 7 days & 14 days & 7 days & 14 days & 7 days & 14 days & 7 days & 14 days \\
\hline TXT & $6.33(0.86)^{A, a}$ & $8.33(0.24)^{A, b}$ & $6.68(0.60)^{B, a}$ & $8.44(0.21)^{A B, b}$ & $2.17(0.56)^{A, a}$ & $3.07(0.69)^{B, b}$ & $2.37(1.31)^{A, a}$ & $3.89(1.99)^{A, a}$ \\
0\% TAT & $6.09(0.81)^{A, a}$ & $8.07(0.12)^{A, b}$ & $6.46(0.46)^{B, a}$ & $8.52(0.19)^{B, b}$ & $2.15(0.53)^{A, a}$ & $3.07(0.52)^{B, b}$ & $2.51(1.11)^{A, a}$ & $3.59(2.27)^{A, a}$ \\
20\% TAT & $6.06(0.57)^{A, a}$ & $8.35(0.29)^{A, b}$ & $5.97(0.50)^{A, a}$ & $8.01(0.41)^{A, b}$ & $1.86(0.36)^{A, a}$ & $2.03(0.60)^{A, a}$ & $2.79(1.66)^{A, a}$ & $4.07(2.26)^{A, a}$ \\
\hline
\end{tabular}

Different capital letters mean statistical significance within columns for each distance $(p<0.05)$.

A

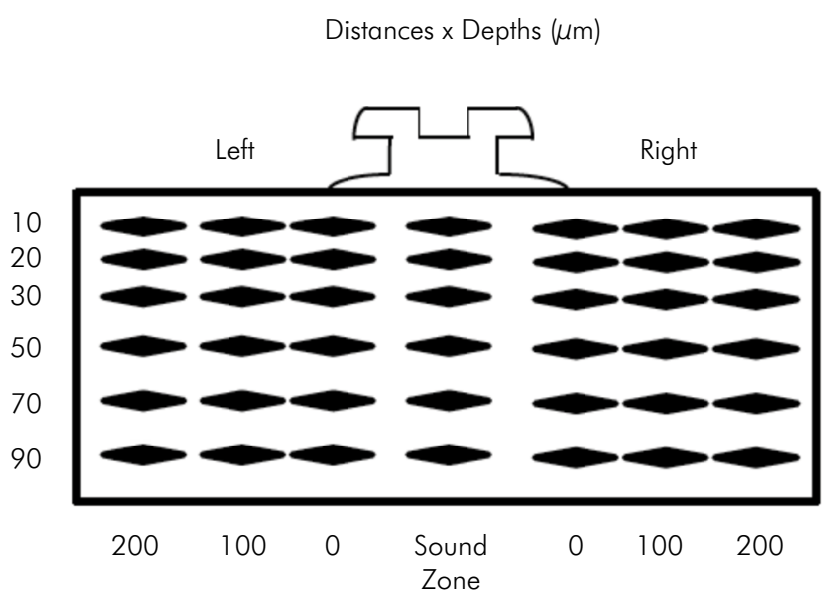

Final mineral loss $=($ Left + Right $) / 2$

C

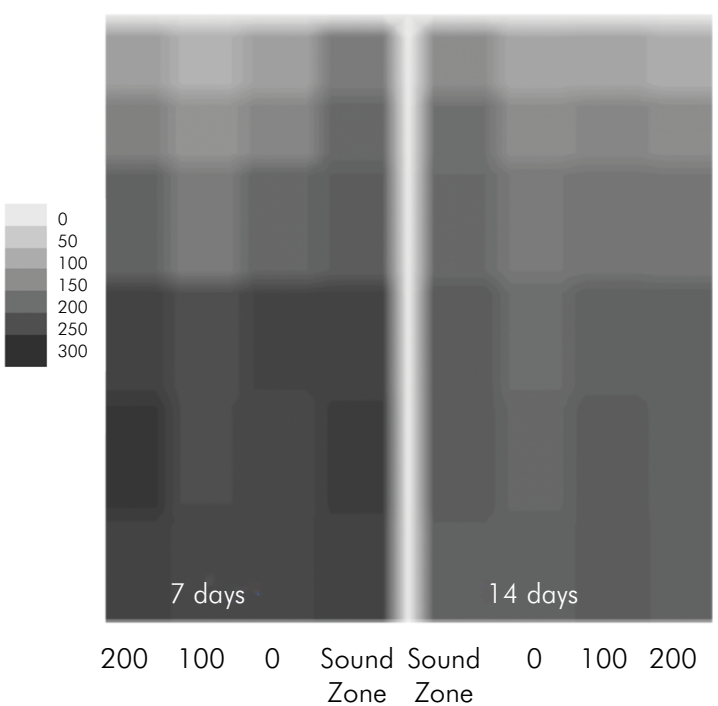

B

TXT

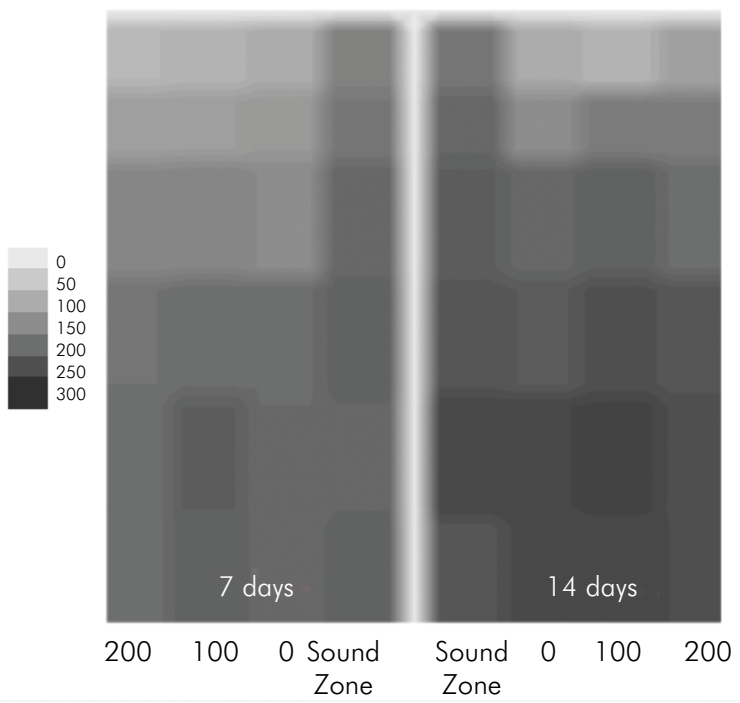

D

TAT 20\%
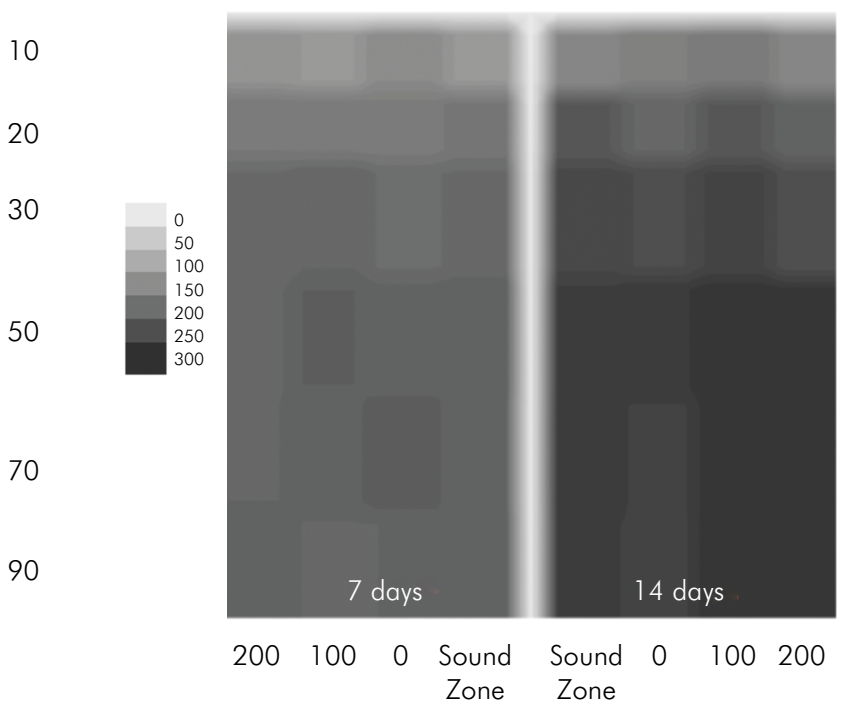

10

Figure 4. (A) Representative image of the microhardness evaluation at different depths (10,20,30,50, 70 and $90 \mu \mathrm{m})$ and different distances (Sound zone, 0, 100, and $200 \mu \mathrm{m}$ ). The equation used for mineral loss measurement is shown. (B) Mineral content increased after 14 days; however, at 10 and $20 \mu \mathrm{m}$ deep, mineral loss may be observed comparing the different distances to the "sound zone". (C) Mineral loss may be observed between the different distances (in $\mu \mathrm{m}$ ) and the "sound zone"; the mineral loss increased at 7 days compared to 14 days. (D) Mineral content increased at 7 days compared to 14 days and no alterations were observed between "sound zone" and the different distances (in $\mu \mathrm{m}$ ). 


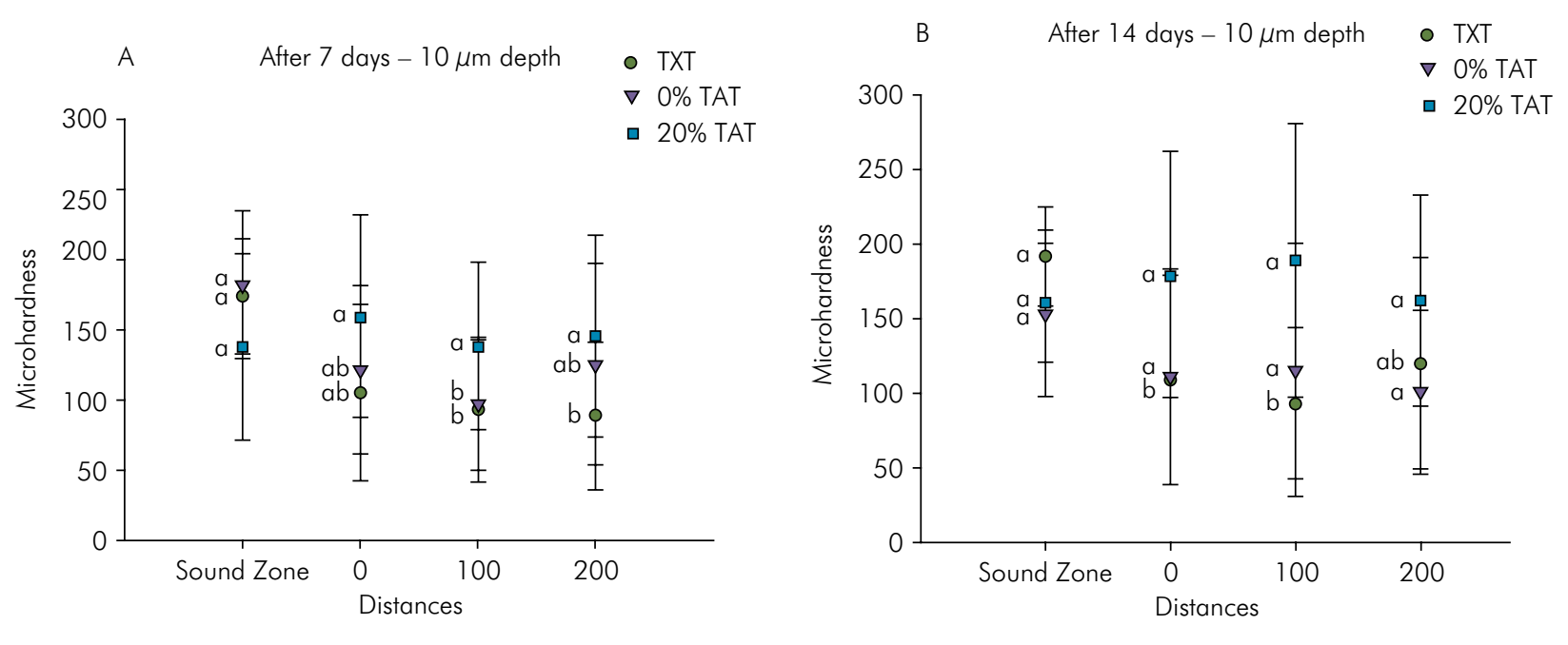

Figure 5. (A) Comparison of microhardness at 10- $\mu \mathrm{m}$ depth after 7 and 14 days among different distances within each group. No alteration was observed for 20\% TAT group while a decrease was observed for TXT and 0\% TAT groups at 100 and $200 \mu \mathrm{m}$ distances. (B) No alteration was observed for 20\% TAT group while a decrease was observed for TXT and 0\% TAT group at 0, 100 , and $200 \mu \mathrm{m}$.

Table 3. Mean and SD of bacteria growth $\left(\log _{10} \mathrm{CFU} / \mathrm{mL}\right)$ of different groups after 7 and 14 days.

\begin{tabular}{|c|c|c|c|c|c|c|c|c|c|c|c|c|}
\hline \multirow{2}{*}{ Variable } & \multicolumn{2}{|c|}{$10 \mu \mathrm{m}$} & \multicolumn{2}{|c|}{$20 \mu \mathrm{m}$} & \multicolumn{2}{|c|}{$30 \mu \mathrm{m}$} & \multicolumn{2}{|c|}{$50 \mu \mathrm{m}$} & \multicolumn{2}{|c|}{$70 \mu \mathrm{m}$} & \multicolumn{2}{|c|}{$90 \mu \mathrm{m}$} \\
\hline & 7 days & 14 days & 7 days & 14 days & 7 days & 14 days & 7 days & 14 days & 7 days & 14 days & 7 days & 14 days \\
\hline \multicolumn{13}{|c|}{ Sound zone } \\
\hline TXT & $\begin{array}{c}174.5 \pm \\
40.6^{A}\end{array}$ & $\begin{array}{c}191.6 \pm \\
32.7 \mathrm{~A}\end{array}$ & $\begin{array}{l}192 \pm \\
63.1^{A}\end{array}$ & $\begin{array}{c}217.7 \pm \\
74.4 \mathrm{~A}\end{array}$ & $\begin{array}{c}215.9 \pm \\
68.7^{A}\end{array}$ & $\begin{array}{c}232.2 \pm \\
71.4 \mathrm{~A}\end{array}$ & $\begin{array}{c}226.3 \pm \\
69.1^{A}\end{array}$ & $\begin{array}{c}246.3 \pm \\
73.4 \mathrm{~A}\end{array}$ & $\begin{array}{c}218 \pm \\
58^{\mathrm{B}}\end{array}$ & $\begin{array}{l}269 \pm \\
80.1 A\end{array}$ & $\begin{array}{c}224.3 \pm \\
71.1^{\mathrm{A}}\end{array}$ & $\begin{array}{c}245.3 \pm \\
64.2^{\mathrm{A}}\end{array}$ \\
\hline TAT O\% & $\begin{array}{c}182.7 \pm \\
52.5^{\wedge}\end{array}$ & $\begin{array}{c}153.4 \pm \\
56 \mathrm{~A}\end{array}$ & $\begin{array}{c}214.4 \pm \\
49.2^{\mathrm{A}}\end{array}$ & $\begin{array}{l}200 \pm \\
83.3 \mathrm{~A}\end{array}$ & $\begin{array}{c}230.9 \pm \\
76.2^{A}\end{array}$ & $\begin{array}{c}210.5 \\
\pm 74.7 \mathrm{~A}\end{array}$ & $\begin{array}{c}275.2 \pm \\
38.1^{A}\end{array}$ & $\begin{array}{l}239 \pm \\
79.3 \mathrm{~A}\end{array}$ & $\begin{array}{c}283.3 \pm \\
46.7^{A}\end{array}$ & $\begin{array}{c}237.7 \pm \\
75.7 A\end{array}$ & $\begin{array}{c}275.8 \pm \\
50.9^{A}\end{array}$ & $\begin{array}{c}228.2 \pm \\
79.7^{\AA}\end{array}$ \\
\hline TAT 20\% & $\begin{array}{c}138.1 \pm \\
66.7^{A}\end{array}$ & $\begin{array}{c}161.1 \pm \\
39.5 \mathrm{~A}\end{array}$ & $\begin{array}{l}194 \pm \\
47.8^{A}\end{array}$ & $\begin{array}{c}240.4 \pm \\
32.7 \mathrm{~A}\end{array}$ & $\begin{array}{c}211.6 \pm \\
50.1^{A}\end{array}$ & $\begin{array}{c}266.6 \pm \\
39.5 A\end{array}$ & $\begin{array}{c}229.8 \pm \\
27.4^{\mathrm{A}}\end{array}$ & $\begin{array}{c}282.7 \pm \\
40.7 A\end{array}$ & $\begin{array}{l}222 \pm \\
29.1^{B}\end{array}$ & $\begin{array}{c}286.1 \pm \\
39.6 \mathrm{~A}\end{array}$ & $\begin{array}{c}228.8 \pm \\
17.6^{A}\end{array}$ & $\begin{array}{c}282.5 \pm \\
38.2^{\mathrm{A}}\end{array}$ \\
\hline \multicolumn{13}{|l|}{$0 \mu \mathrm{m}$} \\
\hline TXT & $\begin{array}{c}105.6 \pm \\
62.9^{A}\end{array}$ & $\begin{array}{c}108.9 \\
\pm 70.1 \mathrm{~A}\end{array}$ & $\begin{array}{c}138.5 \pm \\
79.9^{A}\end{array}$ & $\begin{array}{c}155.3 \pm \\
71 A\end{array}$ & $\begin{array}{c}158.5 \pm \\
77.1^{A}\end{array}$ & $\begin{array}{c}216.4 \pm \\
79.1 \mathrm{~A}\end{array}$ & $\begin{array}{c}207.9 \pm \\
92^{A}\end{array}$ & $\begin{array}{c}239.8 \pm \\
86.1 \mathrm{AB}\end{array}$ & $\begin{array}{c}210.2 \pm \\
90.6^{A}\end{array}$ & $\begin{array}{c}269.2 \\
\pm 77.8 \mathrm{~A}\end{array}$ & $\begin{array}{l}215 \pm \\
89.3^{A}\end{array}$ & $\begin{array}{r}262.9 \\
\pm 76.5^{\wedge}\end{array}$ \\
\hline TAT O\% & $\begin{array}{c}121.8 \pm \\
60.1^{A}\end{array}$ & $\begin{array}{c}111.4 \pm \\
71.6 \mathrm{~A}\end{array}$ & $\begin{array}{c}163.6 \pm \\
87.4^{\mathrm{A}}\end{array}$ & $\begin{array}{c}154.3 \pm \\
104.1 \mathrm{~A}\end{array}$ & $\begin{array}{c}219.1 \pm \\
104^{\AA}\end{array}$ & $\begin{array}{c}189.3 \\
\pm 91.2 \mathrm{~A}\end{array}$ & $\begin{array}{c}270.6 \pm \\
77.9^{A}\end{array}$ & $\begin{array}{c}208.6 \pm \\
81.6 \mathrm{~B}\end{array}$ & $\begin{array}{c}261.9 \pm \\
76.4^{\mathrm{A}}\end{array}$ & $\begin{array}{l}218.1 \\
\pm 88 \mathrm{~A}\end{array}$ & $\begin{array}{c}267.2 \pm \\
66^{A}\end{array}$ & $\begin{array}{c}223.8 \pm \\
76.8^{A}\end{array}$ \\
\hline TAT 20\% & $\begin{array}{c}159.7 \pm \\
72.4^{A}\end{array}$ & $\begin{array}{c}178.9 \pm \\
82.4 \mathrm{~A}\end{array}$ & $\begin{array}{c}184.8 \pm \\
63.3^{\mathrm{A}}\end{array}$ & $\begin{array}{c}219.7 \pm \\
70.8 \mathrm{~A}\end{array}$ & $\begin{array}{c}208.5 \pm \\
51.3^{A}\end{array}$ & $\begin{array}{c}259.7 \\
\pm 59.1 \mathrm{~A}\end{array}$ & $\begin{array}{c}223.6 \pm \\
62.6^{A}\end{array}$ & $\begin{array}{c}288.2 \pm \\
69.3 \mathrm{~A}\end{array}$ & $\begin{array}{c}235.3 \pm \\
61.9^{A}\end{array}$ & $\begin{array}{c}278.4 \pm \\
59.2 \mathrm{~A}\end{array}$ & $\begin{array}{l}220 \pm \\
70.8^{A}\end{array}$ & $\begin{array}{c}277.2 \pm \\
78.7^{A}\end{array}$ \\
\hline \multicolumn{13}{|l|}{$100 \mu \mathrm{m}$} \\
\hline TXT & $\begin{array}{l}93.7 \pm \\
51.8^{A}\end{array}$ & $\begin{array}{c}93.1 \pm \\
51.3 B\end{array}$ & $\begin{array}{l}129 \pm \\
82.5^{A}\end{array}$ & $\begin{array}{c}183.4 \pm \\
89.1 \mathrm{~A}\end{array}$ & $\begin{array}{c}167.9 \pm \\
95.3^{A}\end{array}$ & $\begin{array}{c}227.9 \pm \\
74.3 \mathrm{AB}\end{array}$ & $\begin{array}{c}207.6 \pm \\
94.5^{A}\end{array}$ & $\begin{array}{c}254.1 \pm \\
82.3 \mathrm{~A}\end{array}$ & $\begin{array}{c}230.7 \pm \\
89.1^{\mathrm{A}}\end{array}$ & $\begin{array}{c}275.1 \pm \\
82.2 \mathrm{~A}\end{array}$ & $\begin{array}{c}227.3 \pm \\
87.7^{\AA}\end{array}$ & $\begin{array}{c}263.5 \pm \\
65.5^{\mathrm{A}}\end{array}$ \\
\hline TAT O\% & $\begin{array}{l}97 \pm \\
46.6^{A}\end{array}$ & $\begin{array}{c}115.6 \pm \\
85.3 \mathrm{~B}\end{array}$ & $\begin{array}{c}143.2 \pm \\
52.3^{A}\end{array}$ & $\begin{array}{l}163 \pm \\
99.6 \mathrm{~A}\end{array}$ & $\begin{array}{c}183.9 \pm \\
76.8^{A}\end{array}$ & $\begin{array}{c}195.6 \pm \\
90 B\end{array}$ & $\begin{array}{c}253.8 \pm \\
85.6^{A}\end{array}$ & $\begin{array}{c}226.5 \pm \\
71.6 \mathrm{~A}\end{array}$ & $\begin{array}{c}259.7 \pm \\
66.9^{A}\end{array}$ & $\begin{array}{c}235.3 \pm \\
72.2 \mathrm{~A}\end{array}$ & $\begin{array}{c}266.3 \pm \\
77.4^{\AA}\end{array}$ & $\begin{array}{c}233.6 \pm \\
72.5^{\AA}\end{array}$ \\
\hline TAT 20\% & $\begin{array}{c}138.9 \pm \\
60^{4}\end{array}$ & $\begin{array}{c}188.6 \pm \\
91.6 \mathrm{~A}\end{array}$ & $\begin{array}{c}187.3 \pm \\
59.2^{A}\end{array}$ & $\begin{array}{l}240 \pm \\
83.7 \mathrm{~A}\end{array}$ & $\begin{array}{l}219 \pm \\
72.3^{A}\end{array}$ & $\begin{array}{l}272 \pm \\
58.8 \mathrm{~A}\end{array}$ & $\begin{array}{l}230 \pm \\
68.2^{\mathrm{A}}\end{array}$ & $\begin{array}{c}297.9 \pm \\
67.3 \mathrm{~A}\end{array}$ & $\begin{array}{l}227 \pm \\
65.5^{A}\end{array}$ & $\begin{array}{c}296.1 \pm \\
71.4 \mathrm{~A}\end{array}$ & $\begin{array}{c}218.9 \pm \\
49.6^{A}\end{array}$ & $\begin{array}{c}297.4 \pm \\
71.4^{\mathrm{A}}\end{array}$ \\
\hline \multicolumn{13}{|l|}{$200 \mu \mathrm{m}$} \\
\hline TXT & $\begin{array}{l}89.4 \pm \\
52.6^{\mathrm{A}}\end{array}$ & $\begin{array}{c}120.2 \pm \\
71.5 \mathrm{~A}\end{array}$ & $\begin{array}{c}125.8 \pm \\
58.8^{\AA}\end{array}$ & $\begin{array}{c}181.1 \\
+89.2 \mathrm{~A}\end{array}$ & $\begin{array}{c}164.2 \pm \\
65.5^{A}\end{array}$ & $\begin{array}{c}208.3 \pm \\
72.1 \mathrm{~A}\end{array}$ & $\begin{array}{c}199.9 \pm \\
62.9^{B}\end{array}$ & $\begin{array}{c}244.9 \pm \\
62.9 \mathrm{~A}\end{array}$ & $\begin{array}{c}204.4 \pm \\
70.4^{\mathrm{B}}\end{array}$ & $\begin{array}{c}257.5 \pm \\
53.5 \mathrm{~A}\end{array}$ & $\begin{array}{l}204 \pm \\
75.9^{B}\end{array}$ & $\begin{array}{c}259.9 \pm \\
67.5^{A}\end{array}$ \\
\hline TAT O\% & $\begin{array}{c}125.8 \pm \\
71.9^{A}\end{array}$ & $\begin{array}{c}100.6 \pm \\
54.6 \mathrm{~A}\end{array}$ & $\begin{array}{l}175 \pm \\
82.4^{\mathrm{A}}\end{array}$ & $\begin{array}{c}156.1 \pm \\
67.4 \mathrm{~A}\end{array}$ & $\begin{array}{c}221.9 \pm \\
74.8^{A}\end{array}$ & $\begin{array}{c}191.2 \\
\pm 79.5 \mathrm{~A}\end{array}$ & $\begin{array}{c}277.2 \pm \\
65^{A}\end{array}$ & $\begin{array}{c}226.6 \pm \\
80.6 \mathrm{~A}\end{array}$ & $\begin{array}{c}292.7 \pm \\
65.6^{A}\end{array}$ & $\begin{array}{l}223 \pm \\
84.8 A\end{array}$ & $\begin{array}{c}275.8 \pm \\
59.9^{A}\end{array}$ & $\begin{array}{c}226.6 \pm \\
73.6^{A}\end{array}$ \\
\hline TAT 20\% & $\begin{array}{c}145.9 \pm \\
71.8^{A}\end{array}$ & $\begin{array}{l}162 \pm \\
70.6 \mathrm{~A}\end{array}$ & $\begin{array}{c}189.5 \pm \\
61.9^{A}\end{array}$ & $\begin{array}{r}221.6 \\
\pm 54.2 \mathrm{~A}\end{array}$ & $\begin{array}{c}211.3 \pm \\
65.8^{A}\end{array}$ & $\begin{array}{r}253.8 \\
\pm 49 \mathrm{~A}\end{array}$ & $\begin{array}{c}216.8 \pm \\
71.8^{\mathrm{AB}}\end{array}$ & $\begin{array}{c}293.8 \pm \\
57.7 A\end{array}$ & $\begin{array}{c}219.5 \pm \\
59.8^{\mathrm{B}}\end{array}$ & $\begin{array}{c}297.9 \pm \\
71.8 \mathrm{~A}\end{array}$ & $\begin{array}{c}228.9 \pm \\
56.3^{\mathrm{AB}}\end{array}$ & $\begin{array}{c}290.9 \pm \\
67^{A}\end{array}$ \\
\hline
\end{tabular}

Different capital letters mean statistical significance within columns $(\mathrm{p}<0.05)$; Different lowercase letters mean statistical significance among columns of each bacteria $(p<0.05)$. 
for S. mutans. An increase in total bacteria and total Streptococci was found for all groups while no difference occurred for Lactobacilli between 7 and 14 days. Comparing groups, total Streptococci growth in the 20\% TAT group at 7 and 14 days was lower than TXT and $0 \%$ TAT, and $0 \%$ TAT, respectively. The $S$. mutans growth of $20 \%$ TAT at 14 days was lower than TXT and 0\% TAT (Table 3).

\section{Discussion}

This in situ model simulated the complexity of biofilm formation in vivo and the variability of the oral environment, thus overcoming the ethical and clinical relevance limitations of in vivo ${ }^{22}$ and in vitro experiments, ${ }^{16,17}$ respectively. For the evaluation of novel antimicrobial adhesives, appropriate test systems are required, such as multispecies biofilm models, which mimic the in vivo situation. In situ models testing materials containing antimicrobial ${ }^{23}$ or remineralizing ${ }^{24}$ agents have shown some evidence for reduced mineral loss. Biofilm formation in enamel surfaces claims for highly efficient biomaterials in order to prevent tooth demineralization. This method was used due to a good correlation (0.91) found between enamel microhardness and the percentage of mineral within caries lesion..$^{25}$ Also, to the best of the authors' knowledge, this was the first time that demineralization of the enamel adjacent to brackets bonded with an antibacterial and bioactive adhesive was assessed in situ. In this study, the null hypothesis was rejected since the experimental orthodontic adhesive containing TAT and PIG-Nb promoted inhibition of total Streptococci and S. mutans growth and avoided demineralization of the enamel surface.

Acidogenic bacteria present in the plaque, most notably S. mutans and Lactobacilli, ${ }^{26}$ are responsible for lowering $\mathrm{pH}$ and causing WSLs around brackets within one month after bonding. Although previous in situ studies ${ }^{27,28}$ have shown enamel alterations within 14 days, the greater demineralization after 7 days of sucrose exposure found in this study is in agreement with a previous report. ${ }^{29}$ Mineral loss of enamel within $10 \mu \mathrm{m}$ depth, as found in this study, was well correlated to lesion progression of 1 to $2 \mu \mathrm{m}$ per day in clinical restorations. ${ }^{30}$ Mineral loss was significantly higher in both TXT and $0 \%$ TAT groups compared to $20 \%$ TAT group after 14 days at 0 and $100 \mu \mathrm{m}$ distances of bracket base. Furthermore, in accordance to in situ studies with similar methodology evaluating microhardness over 28 days, ${ }^{18,31}$ demineralization of $0 \%$ TAT and TXT groups within $10 \mu \mathrm{m}$ depth increased at 100 and $200 \mu \mathrm{m}$ distances after 7 days, and 0 and $100 \mu \mathrm{m}$ distances after 7 and 14 days, respectively, compared to "Sound zone". The microhardness measurement of the "Sound zone" was essential to ensure that the results observed (Table 2) were due to mineral loss caused by the acids of the plaque and not by the etching procedure. This is highlighted in Figure $4 \mathrm{~b}$ and $4 \mathrm{c}$, wherein areas with higher mineral content until $30 \mu \mathrm{m}$ were observed at the "Sound zone". No significant difference in bond strengths between TXT and TAT (20.44 \pm 6.23 and $16.33 \pm 5.06$, respectively) found in a previous study ${ }^{10}$ indicated a similar adhesion between both and enamel. A limitation in this study was that authors standardized the initial microhardness found in great depths of enamel, as standardization of teeth was made only at the surface of enamel. Despite the clinical relevance of evaluating re- or de-mineralization in great depths, which could indicate fragility inside the shallow surface of enamel, these alterations were probably caused by its intrinsic characteristics. Previous studies showed no demineralization of enamel over $50 \mu \mathrm{m}$ deep in periods of 7 and 14 days. ${ }^{28,29}$

The mineral content of enamel in the $20 \%$ TAT group at 14 days, as shown in Figures 3 to 5, was a consequence of two main factors: antibacterial activity and mineral deposition. As previously reported, ${ }^{9}$ incorporation of $20 \%$ TAT into an experimental orthodontic adhesive has led to a reduction of $S$. mutans growth, also observed in this study (Table 3) within 14 days. TAT has shown to copolymerize its methacrylate radical with the adhesive's monomers preventing over-time leaching. ${ }^{14}$ The antimicrobial mechanism of TAT is through the mimicking of the hydrophobic pattern of short cationic peptides and is more selective against gram positive bacteria, leading to disruption of Lactobacilli and S. mutans membrane integrity. ${ }^{32}$ Moreover, the surface roughness of restorative materials plays a role in pellicle formation 
and biofilm adhesion. ${ }^{33}$ The smaller inorganic fillers from the phosphate invert glass of $20 \%$ TAT adhesive may have resulted in lower surface roughness ${ }^{34}$ and less bacterial accumulation. However, no inhibition and no difference against total bacteria and Lactobacilli growth was found among the tested adhesives. Lactobacilli growth increased 4 to 10 times more than S. mutans in biofilms formed under exposure to sucrose..$^{35}$ This may explain their great growth after 14 days, as well as the high total bacterial count, outperforming the antibacterial activity of the $20 \%$ TAT adhesive. Another limitation of this study was that plaque collection was not done in different areas to study bacteria specifically from each distance.

Nonetheless, the incorporation of niobium pentoxide phosphate invert glass into the adhesive has promoted mineral deposition in artificial saliva. ${ }^{14}$ Figure 2d illustrates the higher mineral content at 14 compared to 7 days. This could be explained by the presence of bioactive glass promoting the leach of ions resembling those from enamel and their diffusion through the lesion. There is evidence that WSLs are remineralized by the use of bioactive glasses in shortterm evaluation. ${ }^{36}$ Indeed, the increase of mineral content shown in Figure $2 b$ may have occurred due to the higher filler content, such as quartz, silica, and glass, than the $0 \%$ TAT. Also, the addition of niobium pentoxide was done to improve chemical stability of the bioglass and thus increase the duration of mineral deposition. ${ }^{37}$ No previous study with orthodontic antibacterial adhesive has demonstrated the in situ antibacterial efficacy to use it as a positive control group. Previous antibacterial studies of Triazine and phosphate invert glass showed satisfactory results ${ }^{9}$ consistent to antibacterial long-term effects of quaternary ammonium adhesives ${ }^{38}$ instead of chlorhexidine added to the adhesive, which loses protection after $2 \mathrm{~h}^{6}$. Regarding the limitations of the adhesives studied, such as their hydrolytic property ${ }^{39}$ and the microbial ${ }^{40}$ degradation of the polymer matrix, the antibacterial and mineral deposition properties of the experimental 20\% TAT adhesive may result in a tougher adhesive.

In situ models are known to be faster than clinical models and have higher clinical relevance than in vitro models. However, they have some disadvantages as patients are required to wear and care for the appliances. ${ }^{17}$ Aiming to maintain a good oral health and achieving a high compliance of the volunteers during the study, this in situ model recruited students and professors from our dental school. Although a dental-related population is not representative of the general population, ${ }^{41}$ intricate instructions and lack of compliance may lead to exclusion of volunteers. In this study, despite six volunteers excluded from the study, only two were due to compliance issues (delivering absence). Nevertheless, the inclusion of 10 volunteers was in agreement with previous studies having demineralization as outcome. ${ }^{42}$ In this study, all volunteers were submitted to a highly cariogenic substance, which would put them at "high caries risk". However, demineralization did not occur in all groups, showing that other patient factors, e.g. bacterial composition, sugar consumption and saliva, were influencing such prevention, as previously described..$^{20}$

This in situ study was valuable as it evaluated the inhibition of demineralization process ${ }^{43}$ and allowed direct comparison between materials. The adhesive system with antibacterial and bioactive component (20\% TAT) resulted in less total Streptococci and S. mutans growth, which might be attributed to the antibacterial properties of the adhesive and reduced filler size. Due to the study design, the demineralization of enamel may also have been influenced by individual habits, different oral pathogens within the biofilm, and material composition. ${ }^{20}$

\section{Conclusions}

As a conclusion, bonding brackets to enamel with adhesives containing triazine and niobium phosphate invert glass leads to inhibition of demineralization and/or contributes with the recovery of the enamel mineral content under adverse conditions of oral hygiene.

\section{Acknowledgment}

FD would like to acknowledge the support of CAPES for his scholarship. 
Evaluation of an antibacterial orthodontic adhesive incorporated with niobium-based bioglass: an in situ study

\section{References}

1. Tanner AC, Sonis AL, Lif Holgerson P, Starr JR, Nunez Y, Kressirer CA, et al. White-spot lesions and gingivitis microbiotas in orthodontic patients. J Dent Res. 2012 Sep;91(9):853-8. https://doi.org/10.1177/0022034512455031

2. Tufekci E, Dixon JS, Gunsolley JC, Lindauer SJ. Prevalence of white spot lesions during orthodontic treatment with fixed appliances. Angle Orthod. 2011 Mar;81(2):206-10. https://doi.org/10.2319/051710-262.1

3. Julien KC, Buschang PH, Campbell PM. Prevalence of white spot lesion formation during orthodontic treatment. Angle Orthod. 2013 Jul;83(4):641-7. https://doi.org/10.2319/071712-584.1

4. Olivieri A, Ferro R, Benacchio L, Besostri A, Stellini E. Validity of Italian version of the Child Perceptions Questionnaire (CPQ1 1-14). BMC Oral Health. 2013 Oct;13(1):55. https://doi.org/10.1186/1472-6831-13-55

5. Degrazia FW, Genari B, Leitune VC, Arthur RA, Luxan SA, Samuel SM, et al. Polymerisation, antibacterial and bioactivity properties of experimental orthodontic adhesives containing triclosan-loaded halloysite nanotubes. J Dent. 2018 Feb;69(9):77-82. https://doi.org/10.1016/i.jdent.2017.11.002

6. Abu Nawareg M, Elkassas D, Zidan A, Abuelenain D, Abu Haimed T, Hassan AH, et al. Is chlorhexidine-methacrylate as effective as chlorhexidine digluconate in preserving resin dentin interfaces? J Dent. 2016 Feb;45:7-13. https://doi.org/10.1016/i.jdent.2015.11.002

7. Degrazia FW, Leitune VC, Garcia IM, Arthur RA, Samuel SM, Collares FM. Effect of silver nanoparticles on the physicochemical and antimicrobial properties of an orthodontic adhesive. J Appl Oral Sci. 2016 Jul-Aug;24(4):404-10. https://doi.org/10.1590/1678-7757201601543

8. Altmann AS, Collares FM, Leitune VC, Samuel SM. The effect of antimicrobial agents on bond strength of orthodontic adhesives: a metaanalysis of in vitro studies. Orthod Craniofac Res. 2016 Feb;19(1):1-9. https://doi.org/10.1111/ocr.12100

9. Altmann AS, Collares FM, Ogliari FA, Samuel SM. Effect of methacrylated-based antibacterial monomer on orthodontic adhesive system properties. Am J Orthod Dentofacial Orthop. 2015 Apr;147(4 Suppl):S82-7. https://doi.org/10.1016/i.ajodo.2015.01.015

10. Altmann AS, Collares FM, Leitune VC, Arthur RA, Takimi AS, Samuel SM. In vitro antibacterial and remineralizing effect of adhesive containing triazine and niobium pentoxide phosphate inverted glass. Clin Oral Investig. 2017 Jan;21(1):93-103. https://doi.org/10.1007/s00784-016-1754-y

11. Khvostenko D, Hilton TJ, Ferracane JL, Mitchell JC, Kruzic JJ. Bioactive glass fillers reduce bacterial penetration into marginal gaps for composite restorations. Dent Mater. 2016 Jan;32(1):73-81. https://doi.org/10.1016/i.dental.2015.10.007

12. Niu LN, Zhang W, Pashley DH, Breschi L, Mao J, Chen JH, et al. Biomimetic remineralization of dentin. Dent Mater. 2014 Jan;30(1):77-96. https://doi.org/10.1016/i.dental.2013.07.013

13. Hench LL. The story of Bioglass. J Mater Sci Mater Med. 2006 Nov;17(11):967-78. https://doi.org/10.1007/s10856-006-0432-z

14. Collares FM, Portella FF, Fraga GC, Semeunka SM, Almeida LC, Santos ER, et al. Mineral deposition at dental adhesive resin containing niobium pentoxide. Appl Adhes Sci. 2014 Dec;2(1):22. https://doi.org/10.1186/s40563-014-0022-0

15. Chenu S, Lebullenger R, Rocherullé J. Microwave synthesis and properties of NaPO3-SnO-Nb2O5 glasses. J Mater Sci. 2012 Jun;47(11):4632-9. https://doi.org/10.1007/s10853-012-6328-z

16. Altmann AS, Collares FM, Balbinot GS, Leitune VC, Takimi AS, Samuel SM. Niobium pentoxide phosphate invert glass as a mineralizing agent in an experimental orthodontic adhesive. Angle Orthod. 2017 Sep;87(5):759-65. https://doi.org/10.2319/122417-140.1

17. Ferracane JL. Models of caries formation around dental composite restorations. J Dent Res. 2017 Apr;96(4):364-71. https://doi.org/10.1177/0022034516683395

18. Pascotto RC, Navarro MF, Capelozza Filho L, Cury JA. In vivo effect of a resin-modified glass ionomer cement on enamel demineralization around orthodontic brackets. Am J Orthod Dentofacial Orthop. 2004 Jan;125(1):36-41. https://doi.org/10.1016/S0889-5406(03)00571-7

19. Kuper NK, Opdam NJ, Ruben JL, Soet JJ, Cenci MS, Bronkhorst EM, et al. Gap size and wall lesion development next to composite. J Dent Res. 2014 Jul;93(7 Suppl):108S-13S. https://doi.org/10.1177/0022034514534262

20. Cury JA, Rebelo MA, Del Bel Cury AA, Derbyshire MT, Tabchoury CP. Biochemical composition and cariogenicity of dental plaque formed in the presence of sucrose or glucose and fructose. Caries Res. 2000 Nov-Dec;34(6):491-7. https://doi.org/10.1159/000016629

21. Arthur RA, Martins VB, de Oliveira CL, Leitune VC, Collares FM, Magalhães AC, et al. Effect of over-the-counter fluoridated products regimens on root caries inhibition. Arch Oral Biol. 2015 Oct;60(10):1588-94. https://doi.org/10.1016/i.archoralbio.2015.07.018

22. Salli KM, Ouwehand AC. The use of in vitro model systems to study dental biofilms associated with caries: a short review. J Oral Microbiol. 2015 Mar;7(1):26149. https://doi.org/10.3402/jom.v7.26149

23. Sande FH, Opdam NJ, Truin GJ, Bronkhorst EM, Soet JJ, Cenci MS, et al. The influence of different restorative materials on secondary caries development in situ. J Dent. 2014 Sep;42(9):1171-7. https://doi.org/10.1016/i.jdent.2014.07.003

24. Melo MA, Weir MD, Rodrigues LK, Xu HH. Novel calcium phosphate nanocomposite with caries-inhibition in a human in situ model. Dent Mater. 2013 Feb;29(2):231-40. https://doi.org/10.1016/j.dental.2012.10.010 
25. Featherstone JD, ten Cate JM, Shariati M, Arends J. Comparison of artificial caries-like lesions by quantitative microradiography and microhardness profiles. Caries Res. 1983;17(5):385-91. https://doi.org/10.1159/000260692

26. Türkkahraman H, Sayin MO, Bozkurt FY, Yetkin Z, Kaya S, Onal S. Archwire ligation techniques, microbial colonization, and periodontal status in orthodontically treated patients. Angle Orthod. 2005 Mar;75(2):231-6.

27. Cenci MS, Tenuta LM, Pereira-Cenci T, Del Bel Cury AA, ten Cate JM, Cury JA. Effect of microleakage and fluoride on enameldentine demineralization around restorations. Caries Res. 2008;42(5):369-79. https://doi.org/10.1159/000151663

28. Gameiro GH, Nover DF, Cenci MS, Cury JA. Enamel demineralization with two forms of archwire ligation investigated using an in situ caries model_a pilot study. Eur J Orthod. 2009 Oct;31(5):542-6. https://doi.org/10.1093/ejo/cjn119

29. Vale GC, Tabchoury CP, Arthur RA, Del Bel Cury AA, Paes Leme AF, Cury JA. Temporal relationship between sucroseassociated changes in dental biofilm composition and enamel demineralization. Caries Res. 2007;41(5):406-12. https://doi.org/10.1159/000105764

30. Thomas RZ, Ruben JL, ten Bosch JJ, Fidler V, Huysmans MC. Approximal secondary caries lesion progression, a 20-week in situ study. Caries Res. 2007;41(5):399-405. https://doi.org/10.1159/000104799

31. Moura MS, Simplício AHM, Cury JA. In-vivo effects of fluoridated antiplaque dentifrice and bonding material on enamel demineralization adjacent to orthodontic appliances. Am J Orthod Dentofacial Orthop. 2006 Sep;130(3):357-63. https://doi.org/10.1016/i.ajodo.2004.12.026

32. Zhou C, Min J, Liu Z, Young A, Deshazer H, Gao T, et al. Synthesis and biological evaluation of novel 1,3,5-triazine derivatives as antimicrobial agents. Bioorg Med Chem Lett. 2008 Feb;18(4):1308-11. https://doi.org/10.1016/j.bmcl.2008.01.031

33. Kuper NK, Montagner AF, van de Sande FH, Bronkhorst EM, Opdam NJ, Huysmans MC. Secondary caries development in in situ gaps next to composite and amalgam. Caries Res. 2015;49(5):557-63. https://doi.org/10.1159/000438728

34. Moraes RR, Gonçalves LS, Lancellotti AC, Consani S, Correr-Sobrinho L, Sinhoreti MA. Nanohybrid resin composites: nanofiller loaded materials or traditional microhybrid resins? Oper Dent. 2009 Sep-Oct;34(5):551-7. https://doi.org/10.2341/08-043-L

35. Minah GE, Lovekin GB, Finney JP. Sucrose-induced ecological response of experimental dental plaques from caries-free and cariessusceptible Human volunteers. Infect Immun. 1981 Dec;34(3):662-75.

36. Milly H, Festy F, Watson TF, Thompson I, Baneriee A. Enamel white spot lesions can remineralise using bio-active glass and polyacrylic acid-modified bio-active glass powders. J Dent. 2014 Feb;42(2):158-66. https://doi.org/10.1016/i.jdent.2013.11.012

37. Knowles JC, Franks K, Abrahams I. Investigation of the solubility and ion release in the glass system $\mathrm{K} 2 \mathrm{O}-\mathrm{Na} 2 \mathrm{O}-\mathrm{CaO}-\mathrm{P} 2 \mathrm{O} 5$. Biomaterials. 2001 Dec;22(23):3091-6. https://doi.org/10.1016/S0142-9612(01)00057-6

38. Imazato S, Kinomoto Y, Tarumi H, Ebisu S, Tay FR. Antibacterial activity and bonding characteristics of an adhesive resin containing antibacterial monomer MDPB. Dent Mater. 2003 Jun;19(4):313-9. https://doi.org/10.1016/S0109-5641(02)00060-X

39. Ferracane JL. Hygroscopic and hydrolytic effects in dental polymer networks. Dent Mater. 2006 Mar;22(3):211-22. https://doi.org/10.1016/i.dental.2005.05.005

40. Zhang N, Ma Y, Weir MD, Xu HH, Bai Y, Melo MA. Current insights into the modulation of oral bacterial degradation of dental polymeric restorative materials. Materials (Basel). 2017 May;10(5):507. https://doi.org/10.3390/ma10050507

41. Sung YH, Kim HY, Son HH, Chang J. How to design in situ studies: an evaluation of experimental protocols. Restor Dent Endod. 2014 Aug;39(3):164-71. https://doi.org/10.5395/rde.2014.39.3.164

42. Sousa RP, Zanin IC, Lima JP, Vasconcelos SM, Melo MA, Beltrão HC, et al. In situ effects of restorative materials on dental biofilm and enamel demineralisation. J Dent. 2009 Jan;37(1):44-51. https://doi.org/10.1016/i.jdent.2008.08.009

43. Cochrane NJ, Zero DT, Reynolds EC. Remineralization models. Adv Dent Res. 2012 Sep;24(2):129-32. https://doi.org/10.1177/0022034512453845 